\title{
Pollution indicator species of macrobenthos in a coastal lagoon
}

\author{
Raymond E. Grizzle \\ Department of Biological Sciences, Nelson Biological Laboratory, Rutgers University, P.O.Box 1059, \\ Piscataway, New Jersey 08854, USA
}

\begin{abstract}
Life history differences and effects of physicochemical changes on macrobenthos of coastal lagoons were studied for $2 \mathrm{yr}$ at one site in the sewage-polluted, moderately enriched Sykes Creek and a comparison site in the less-polluted Banana River, Florida, USA. Monthly and bi-monthly quantitative sediment samples for faunal analyses were taken from the natural substratum, and recolonization of defaunated sediments set out at 4 different times in $1 \mathrm{yr}$ was monitored concurrently. The top 4 numerical dominants in natural substratum samples from Sykes Creek, i.e. the indicator species, were: Corophium ellisi, Haploscoloplos foliosus, Capitella capitata, Anomalocardia auberiana. Based on recolonization experiments all 4 were identified as opportunistic. However, the top 2 numerical dominants in the Creek (C. ellisi, $H$. foliosus) also relied on their abilities to exploit food and/or space. Banana River benthos contained a greater relative abundance of equilibrium species and fewer opportunistic species compared to Sykes Creek, suggesting that there has been a shift toward a life history strategy of opportunism in the enriched area. With a lag shift of 2 mo, dissolved oxygen and temperature from the Creek were strongly correlated with macrobenthic density. Also, drastic declines involving most species present were observed in early summer in 1978 and 1979 coinciding (no 2-mo lag) with oxygen/temperature extremes of $<2.5 \mathrm{mg} \mathrm{l}^{-1} / 29^{\circ} \mathrm{C}$. These data suggest that the pollution indicator species were as intolerant of oxygen/temperature extremes as non-indicator species. Thus, the numerical dominance of the indicator species in shallow water and sand sediments in Sykes Creek can likely be explained by some combination of superior abilities related to quick invasion and exploitation of food and/or space, competitive interactions could be important. Further concurrent testing of hypotheses is needed. Investigation of the indicator concept was posed as one of the best ways to determine the effects of organic pollution on benthos.
\end{abstract}

\section{INTRODUCTION}

The term 'pollution indicator species' is often used (e.g. Reish, 1960, 1979) to refer to certain macrofaunal benthic species occurring in organically enriched coastal waters. Even though the term has been employed in somewhat different ways by different investigators, the most common use appears to be in reference to species that numerically dominate the macrobenthos in organically enriched areas (Reish, 1960, 1979; Pearson and Rosenberg, 1978; Gray, 1979 , 1981; Young and Young, 1982). In the present report 'indicator species' will simply mean species that have been reported as numerical dominants in organically enriched waters. Two major explanations have been put forth to account for this dominance: (1) superior tolerance to presumably stressful conditions (Filice, 1959; Reish 1979); (2) superior invasion abilities (i.e. opportunism, see below) following sporadic pollution- induced disturbances (Pearson and Rosenberg, 1978; Gray, 1979, 1980, 1981). However, Gray (1981) noted that neither of these explanations has been welltested. Further, in their comprehensive review of the effects of organic enrichment on macrobenthos of coastal waters Pearson and Rosenberg (1978) showed that nearly all pertinent studies were descriptive field investigations, and indicator species have been reported as numerical dominants in areas that differ widely in levels of pollution effects. Thus, there is no good understanding of why indicator species are able to dominate numerically, and it is likely that several different explanations are needed.

Hypoxia is considered to be the major stress factor in many enriched areas (Pearson and Rosenberg, 1978; Pearson, 1980); superior tolerance to low dissolved oxygen concentrations has often been suggested for indicator species (see Pearson and Rosenberg 1978 for review). But few data are available to allow compari- 
son of tolerances of marine invertebrates (Hart and Fuller, 1979; Boesch and Rosenberg, 1981). Further, one set of laboratory experiments showed that the pollution indicator species Capitella capitata was less tolerant of hypoxia than some species associated with the less-polluted areas (Reish, 1967).

Opportunism has been defined in several ways for marine benthos (see Zajac and Whitlatch, 1982 for brief review), and the concepts involved are by no means settled. For example, Parry (1981) noted that the relations of various characteristics generally attributed to $r$ - and $K$-strategists, and even the meanings of the terms themselves, are not straightforward and consistent in the literature. Also, Thistle (1981) discussed aspects of competition and food exploitation not emphasized in earlier reports concerned with opportunism. Further, Zajac and Whitlatch (1982) suggested that designation of species as opportunists may depend more on historical (relative to experiments) environmental variability than on a particular suite of life history traits; they considered those species with significantly higher densities in early recolonization samples compared to ambient samples as opportunists. But regardless of gaps in our knowledge some species of marine benthos have clearly been shown to colonize vacant habitat rapidly in an 'opportunistic' manner. The essential meaning (based on MacArthur, 1960; Grassle and Grassle, 1974; and McCall, 1977; and when considering only population data) of an opportunistic species is one that is able to invade newly available habitat quickly and do so in relatively large numbers; rapid dieoffs usually follow, resulting in high population variability in space and time. This is the sense in which 'opportunism' is used in the present report. Grassle and Grassle (1974) demonstrated that Capitella capitata is opportunistic, showing quick invasion by large numbers of postlarval juveniles in defaunated sediments but only temporarily being dominant. More recent studies (McCall, 1977; Santos and Simon, 1980; Zajac and Whitlatch, 1982) have shown other pollution indicator species to be opportunistic. Thus, it has been suggested that indicator species are able to dominate because they can quickly re-populate areas affected by pollution-induced disturbances (Gray, 1979, 1981). However, it is not known to what extent being relatively more opportunistic is responsible for the dominance of these species in polluted areas. For example, Young and Young (1982) discussed data suggesting that $C$. capitata may in fact be a good competitor for space and/or food. Other indicator species also appear to be superior competitors for space and/or food supplies (see below). Therefore, while tolerance abilities and relative opportunism may explain some cases of the dominance of indicator species, other factors are likely involved.
The life history strategy of opportunism may be contrasted with 'equilibrium' species; in the present study this term is employed in the sense used by McCall (1977). He compared opportunistic and equilibrium species of macrobenthos in Long Island Sound. Equilibrium species always had low densities, typically constant in space and time. Whereas opportunists showed widely fluctuating population densities. McCall also showed that opportunistic species only dominated at shallow-water stations where storminduced wave disturbances affect the benthos. If pollution indicator species are able to dominate enriched areas because they can quickly invade after pollutioninduced disturbance (see above), then it may be expected that the relative abundance in the benthos of species with these two different life history strategies would be affected by enrichment.

I present here data that suggest that neither of the above 2 hypotheses (tolerance, opportunism) is adequate to explain the dominance of indicator species in Sykes Creek, the moderately polluted study area, and that biotic interactions such as competition should be further investigated. The macrobenthos of Sykes Creek previously showed large temporal variability, and a few species which had some opportunistic characteristics were numerically dominant (Grizzle, 1979). The present study was designed as a field experiment to determine if the dominant macrobenthic species in the Creek were the most opportunistic, and to determine if near-bottom oxygen (and other physicochemical measurements) fluctuations coincided with macrobenthic changes; thereby providing limited field tests of the opportunism and tolerance hypotheses, respectively. The study objectives were: (1) identify those species displaying the most opportunistic and equilibrium characteristics using recolonization experiments; (2) assess ambient macrobenthos based on abundance of species displaying these two life history types; (3) relate physicochemical data to macrobenthic data.

The present study was conducted at 2 sites, one in the polluted Sykes Creek and one in the less-polluted Banana River. The Banana River site was chosen to be as similar as possible to the Sykes Creek site, except with respect to enrichment (see below). Therefore, an assumption in the present study is that the differences between the two sites in macrobenthic characteristics may be largely attributed to the effects of enrichment of the water column. The Banana River site is thus termed 'comparison' site.

\section{STUDY AREAS}

Study sites were located in coastal waters of Brevard County, Florida, USA. These sites, Sykes Creek and 
Banana River, may be classified as mixohalineeuhaline estuaries (Cowardin et al., 1979), but are perhaps more aptly described as coastal lagoons. They are part of the east-central Florida Indian River coastal lagoon system (Grizzle, 1979; Fig. 1).

Station A was located on the east side of Sykes Creek about $2 \mathrm{~km}$ north of State Road 520 (Fig. 1). In this area the Creek is about $0.5 \mathrm{~km}$ wide and is bordered by finger-fill canal residential developments on the west side, and impounded mangrove marsh on the east. A filled causeway area and dense commercial and residential developments are immediately to the south. Comparison Station B was located near the east side of the Banana River just off the north shore of State Road 401. The lagoon in this area is about $5.5 \mathrm{~km}$ wide, and is bordered by a US government installation with low density development to the east and west, and access roads and filled causeway to the south.

Over the 2 yr study period salinity values ranged from 16 to $30 \%$ at Station A, and early morning water temperatures were from 8.0 to $29.5^{\circ} \mathrm{C}$. Water depths were $<1 \mathrm{~m}$. Sediment size class analyses were done (Holme and McIntyre, 1971) on samples taken in April 1977 and November 1978, and showed the following mean values: $90.6 \%$ sand (particles $>0.062 \mathrm{~mm}$ ), $8.6 \%$ silt-clay (particles $<0.062 \mathrm{~mm}$ ), $0.8 \%$ shell (all particles $>1 \mathrm{~mm}$ ), and $1.3 \%$ volatile materials (loss after $1 \mathrm{~h}$ at $500^{\circ} \mathrm{C}$ ). Vegetation consisted primarily of the seagrasses Halodule wrightii as dominant, with some Syringodium filiforme and Ruppia maritima. Numerous epiphytic algal species were observed. Water depths and vegetation types and coverages at Station B were very similar to Station A. Salinities at B ranged from 20 to $33 \%$ and temperatures ranged from 6.5 to $29^{\circ} \mathrm{C}$. Sediment samples taken the same time as at Station A were: $88.4 \%$ sand, $11.0 \%$ silt-clay, $0.6 \%$ shell, and $2.0 \%$ volatile.

About $5.5 \times 10^{6} \mathrm{l} \mathrm{d}^{-1}$ of secondarily treated sewage effluents and an undetermined, but substantial, amount of urban stormwater runoff entered Sykes Creek during the study period in the area of Station A. The nearest residential areas and/or sewage effluent discharges to Station B are approximately $2.5 \mathrm{~km}$ to the south and $8.0 \mathrm{~km}$ to the north. Chemical parameters related to enrichment were only occasionally measured during the study. However, data are available (Betz Engineers and Brevard County Health Department, unpubl.) from near the study sites (Table 1). Values from samples taken within $1 \mathrm{~km}$ of Station A and $5 \mathrm{~km}$ of Station B are presented. Phosphorus (Total $\mathrm{PO}_{4}$ as P) and chlorophyll a ( $\mathrm{Chl} \mathrm{a}$ ) concentrations were higher $(\mathrm{p}<0.001)$ at Station A than at B. Total Kjeldahl nitrogen (TKN) was higher at Station B ( $p<0.01$ ). Banana River lagoon in its entirety has unexplained high TKN concentrations. However, near Station B other measures of eutrophication are low, especially Chl a concentrations (Table 1). Also, I have observed several fish kills in Sykes Creek previous to
Fig. 1. Locations of Station A in Sykes Creek and Station B in Banana River

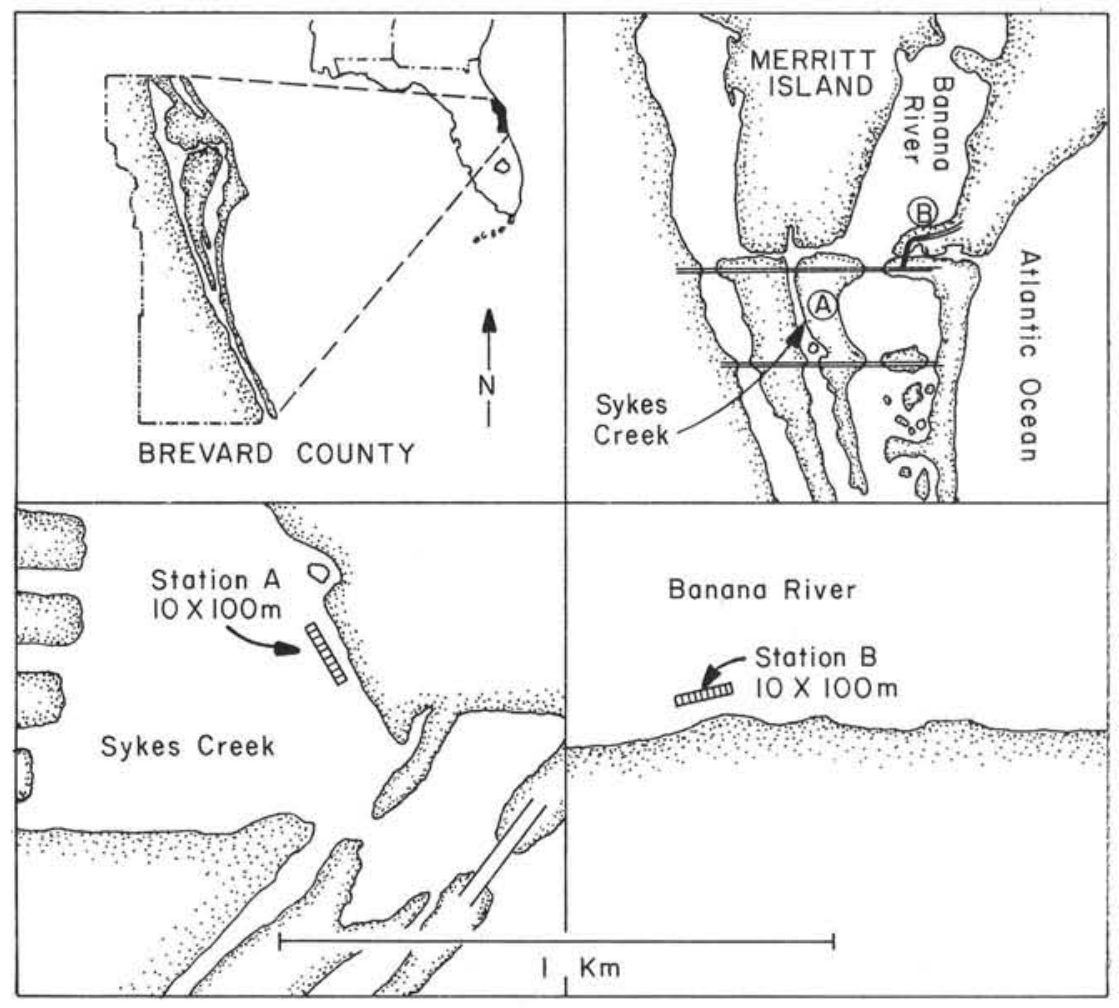


Table 1. Selected water quality parameters collected near Stations A and B from 1976 through 1979. Total Kjeldahl nitrogen (TKN) values were higher at Station $\mathrm{B}\left(\mathrm{P}<0.01\right.$, Mann-Whitney U test), but total phosphate as phosphorus $\left(\mathrm{T}-\mathrm{PO}_{4}\right.$ as $\left.\mathrm{P}\right)$ and chlorophyll a $(\mathrm{Chl}$ a) were higher at Station A $(\mathrm{P}<0.001$, Mann-Whitney U test)

\begin{tabular}{|c|c|c|c|c|c|c|}
\hline & \multicolumn{3}{|c|}{ Station A, Sykes Creek } & \multicolumn{3}{|c|}{ Station B, Banana River } \\
\hline & $\begin{array}{c}\text { TKN } \\
\left(\mathrm{mg} \mathrm{l}^{-1}\right)\end{array}$ & $\begin{array}{c}\mathrm{T}-\mathrm{PO}_{4} \text { as } \mathrm{P} \\
\left(\mathrm{mg} \mathrm{l}^{-1}\right)\end{array}$ & $\underset{\left(\mathrm{mg} \mathrm{m}^{-3}\right)}{\mathrm{Chl} \mathrm{a}}$ & $\begin{array}{c}\text { TKN } \\
\left(\mathrm{mg} \mathrm{l}^{-1}\right)\end{array}$ & $\begin{array}{c}\mathrm{T}-\mathrm{PO}_{4} \text { as } \mathrm{P} \\
\left(\mathrm{mg} \mathrm{l}^{-1}\right)\end{array}$ & $\begin{array}{c}\mathrm{Chl} \mathrm{a} \\
\left(\mathrm{mg} \mathrm{m}^{-3}\right)\end{array}$ \\
\hline Mean & 1.02 & 0.18 & 30.43 & 1.30 & 0.04 & 4.59 \\
\hline Range & $<0.01-1.40$ & $0.09-0.26$ & $6.26-59.46$ & $0.70-1.85$ & $<0.01-0.11$ & $0.10-14.50$ \\
\hline $\mathrm{n}$ & 15 & 17 & 21 & 19 & 24 & 30 \\
\hline
\end{tabular}

the present study, and found these to be associated with hypoxic conditions and algal blooms. No fish kills were observed during the present study in either study area.

\section{MATERIALS AND METHODS}

\section{Field collections}

Collections of macrobenthos from the natural substratum ('ambient' samples) were made at Stations A and B (Fig. 1) at monthly intervals from Jul 1977 through Jun 1978, and at bi-monthly intervals from Aug 1978 through Jul 1979. Samples were taken with a hand-held PVC coring device $15 \mathrm{~cm}$ in diameter, to a depth of about $12 \mathrm{~cm}$. Each sample was a composite of 6 cores, except on 3 occasions (Jul, Dec 1977 and May 1978) when the cores were analyzed individually. Cores were taken in a haphazard fashion only in unvegetated areas. Each sampling station covered an area of approximately $10 \times 100 \mathrm{~m}$. Only unvegetated areas were sampled so as to make the ambient data as comparable as possible to the recolonization data (methods below).

Each sample was sieved on a $0.5 \mathrm{~mm}$ sieve and the residue fixed in $5 \%$ formalin and stained with rose bengal. Animals were sorted in the lab and preserved in $80 \%$ ethanol or isopropanol. All specimens were identified, in most cases to species, and enumerated.

For recolonization studies at both sites sediments were taken from the natural substratum at Station A, and were defaunated by 1 of 2 processes. The first consisted of placing the sediment directly into circular plastic dish pans $8 \mathrm{~cm}$ deep and $0.05 \mathrm{~m}^{2}$ in area at the top, allowing it to dry, then re-wetting with tap water. This drying and wetting process was continued for $5 \mathrm{wk}$. As a check on effectiveness the contents of 2 pans were sieved; no living macroinvertebrates were found. The second process involved placing the sediments into black plastic bags, sealing them, and allowing them to remain exposed to the sun for about $15 \mathrm{wk}$ during summer. Temperatures of $40^{\circ} \mathrm{C}$ were measured in sediments in the bags. Parts of the contents of several bags were sieved and no living macroinvertebrates were found.

After defaunation, sediments were returned to the study sites in plastic pans which had been filled to just below the lip with sediment. Pans were individually covered with plastic sheeting and nestled about $5 \mathrm{~cm}$ into the natural substratum. After the turbidity caused by disturbing the substratum was dissipated the plastic sheeting was removed. Six to 20 pans of defaunated sediment were placed at each station on 1 Dec 1977 , 20 Mar, 9 Jun, and 21 Sep 1978, allowing recolonization sequences initiated at four different times of the year to be monitored. Two pans were removed at each sampling, which occurred at monthly to bi-monthly intervals, by individually placing a fine-mesh nylon cloth over the top of each pan, and slowly raising it to the surface. The contents were emptied into a $0.5 \mathrm{~mm}$ mesh sieve and processed. The two pans were composited for a single sample which was treated as the ambient samples.

Oxygen, salinity, temperature, and $\mathrm{pH}$ of the nearbottom waters were measured in situ using a dissolved oxygen/temperature meter, refractometer, and $\mathrm{pH}$ meter. Each station was monitored at approximately weekly to bi-weekly intervals, but up to several times per week during the summer. A total of 91 measurements were made at Station A and 50 at Station B during the $2 \mathrm{yr}$ study. Measurements were always within $2 \mathrm{~h}$ after sunrise when oxygen concentrations would be minimal for any $24 \mathrm{~h}$ period. Temperature would be minimal for that day, but would still reflect the occurrence of maximum temperatures late in the day.

A species was considered 'common' and subjected to further analyses if it met at least one of the following criteria: (1) present in at least $80 \%$ of the ambient samples (15 of 19 at Station A, or 14 of 17 at B); (2) present in at least $80 \%$ of the ambient samples when the recolonization pans were in place ( 8 of 10 at both stations); (3) present in any sample at a density of $>1,000$ organisms $\mathrm{m}^{-2}$. These criteria would include all persistent species so that adequate data would be available for analyses, and all species with at least transient dominance and thus possible opportunistic 
characteristics. The criteria were applied independently to each station.

\section{RESULTS AND DISCUSSION}

Samples from enriched Station A yielded 96 species; Station B yielded 121 species. From both stations a total of 131 species was collected, with 86 occurring at both stations. Thus all but 10 of the species from Station A occurred at B, plus an additional 35 species. (See Grizzle, 1981, for a complete species list and all sampling data.)

\section{Objective 1: Identify opportunistic and equilibrium species using recolonization data}

Recolonization experiments were done mainly to identify species which were the most opportunistic, and those with equilibrium characteristics. There was no intention to fully examine the disturbance-recolonization patterns per se.

Species exceeding 2,000 organisms $\mathrm{m}^{-2}$ in any of the first samples (which were from experimental pans that had been in place for 14 to 34 d) taken in the 4 recolonization sequences, and followed by a population crash, were defined as opportunistic. All instances of opportunism except 1 were at Station A, and included: Corophium ellisi, Anomalocardia auberiana, Grandidierella bonnieroides, Parasterope pollex, Haploscoloplos foliosus, Capitella capitata, and a podocopan ostracod (Fig. 2). No species appeared to be a clearly superior invader, if gauged by extremely high densities compared to ambient in early recolonization samples (cf. Grassle and Grassle, 1974; McCall, 1977). A. auberiana and $G$. bonnieroides were the only 2 to show more than 1 event of rapid invasion/population crash, and substantially exceed ambient densities (Fig. 2). Also, in most cases of rapid early invasion the population in the natural substratum was expanding. Two additional species occurred in high densities in recolonization sample pans, but only in pans that had been in place for several months at Station A: Parastarte triquetra $\left(6,600 \mathrm{~m}^{-2}\right)$ and Gammarus mucronatus $\left(4,500 \mathrm{~m}^{-2}\right)$. These 2 species did not show such high densities in other recolonization or ambient samples. At Station A there was much more temporal variability in benthic densities compared to Station $B$, and seasonal patterns were clearly evident at A (Fig. 3 and 4; see objective 3 below). The benthos at A experienced a regular summer disturbance, with subsequent recolonization the remainder of the year. The effects of this on the recolonization experiments and identification of opportunists is not clear.
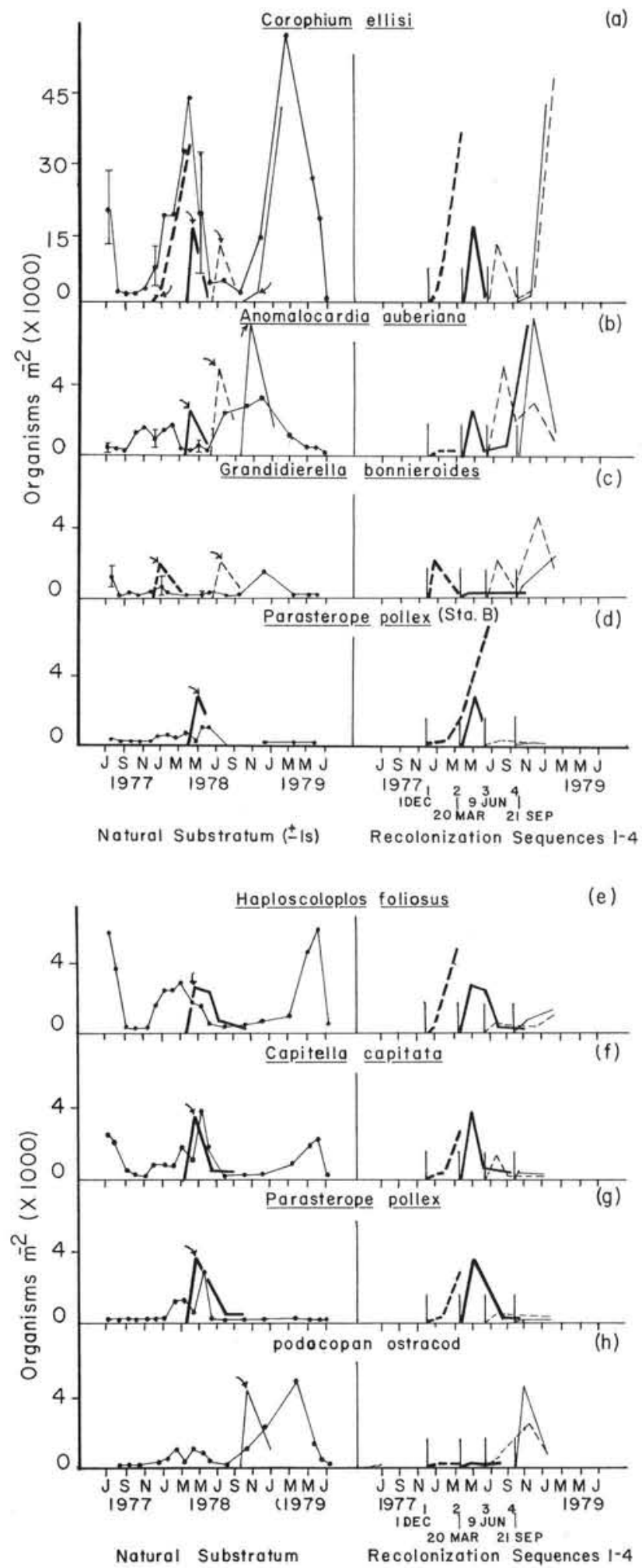

Fig. 2. Population densities of the 7 opportunistic species. Natural substratum (ambient) means for Jul and Dec 1977 and May 1978 show \pm 1 standard deviation (s) when available. When each species exceeded $2,000 \mathrm{~m}^{-2}$ incidences in an early recolonization sample are superimposed on natural substratum data. All from Station A, except P. pollex (d) 


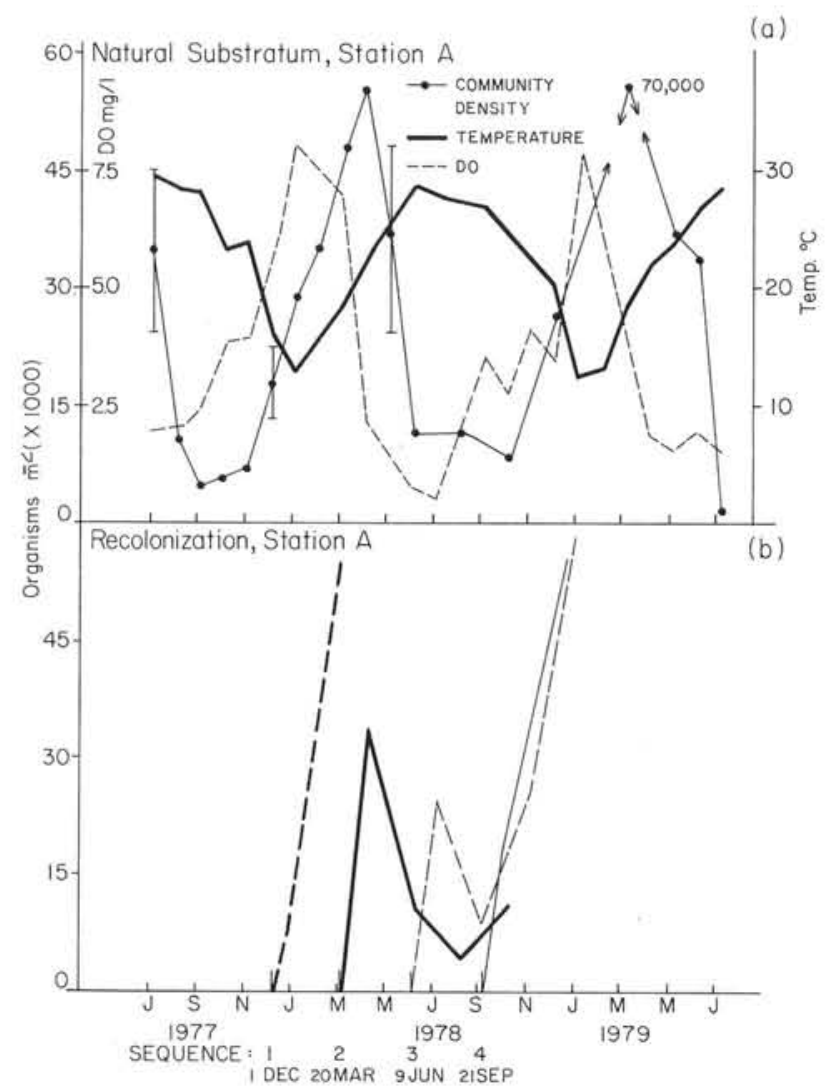

Fig. 3. Station A, Sykes Creek. (a) Natural substratum (ambient) community densities with early morning dissolved oxygen (DO) concentrations and temperatures; (b) community densities for the 4 recolonization sequences. Bars on community density means: \pm 1 standard deviation

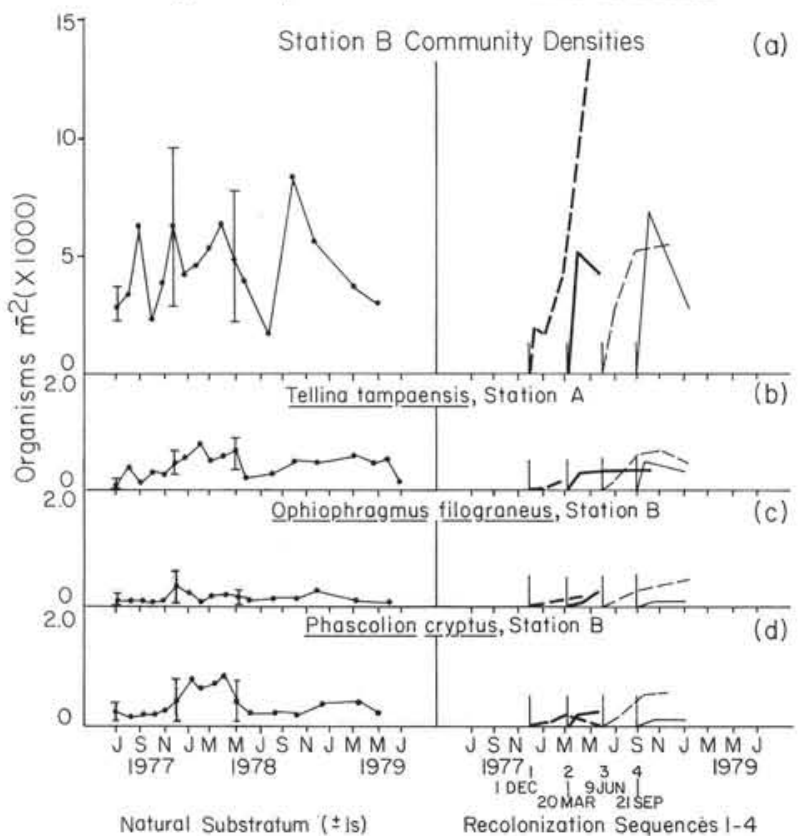

Fig. 4. (a) Station B, Banana River community densities, natural substratum (ambient) and recolonization; (b), (c) and (d) population densities of the 3 equilibrium species. All natural substratum mean densities for Jul and Dec 1977 and May 1978 have bars showing \pm 1 standard deviation (s)
These data generally corroborate the findings of Zajac and Whitlatch (1982) that the response to smallscale disturbance (in an environmentally variable area; see Boesch and Rosenberg, 1981) is very variable over time, and is largely affected by ambient populations. Generally the top numerical dominants in the ambient samples were the most abundant in the recolonization samples at Station A, and the top 5 ambient species were considered opportunistic (Table 2; Fig. 2). However, as discussed below interspecific interactions such as competition must be investigated; the ability to invade quickly and consistently was particularly not evident for the very abundant Haploscoloplos foliosus, and to some extent for Corophium ellisi, the most abundant ambient species at Station A (Fig. 2a, e). Also, the most abundant species at Station B was identified as an equilibrium species (see data below), and the one species identified as opportunistic at Station B ranked only fourth in abundance in samples from the natural substratum (Table 2). Therefore, even though ambient populations affected recolonization patterns, species other than the most abundant in the natural substratum responded to disturbance in an opportunistic manner.

Equilibrium species were defined as those with: low to moderate maximum densities (never exceeding $1,100 \mathrm{~m}^{-2}$ ) in all samples; persistent presence in ambient samples over the 2 yr study period; recolonization patterns invariably rising to a low peak density and remaining fairly stable (Fig. 4). These species were, at Station A: Tellina tampaensis; at Station B: Ophiophragmus filograneus and Phascolion cryptus.

\section{Objective 2: Assess ambient data based on abundance of opportunistic and equilibrium species}

In referring to data from the present study 'indicator' species will mean the numerical dominants at the polluted Station A, the top 4 being: Corophium ellisi, Haploscoloplos foliosus, Capitella capitata, Anomalocardia auberiana (Table 2). All 4 were identified as opportunistic, and more instances of opportunistic invasions occurred at Station A than at B. However, the 2 most abundant species, $C$. ellisi and $H$. foliosus, did not rely solely on quick invasion abilities in order to attain numerical dominance. For instance, densities in recolonization pans were usually lower than ambient for both species. C. ellisi slowly rose to peak densities late in 3 of the 4 recolonization sequences; in sequence \#2 it increased then decreased, never exceeding ambient densities (Fig. 2a). H. foliosus only exceeded $2,000 \mathrm{~m}^{-2}$ in one early recolonization sample, and rose to a peak density in sequence \# 1 after $110 \mathrm{~d}$, at which time 37 species were present in the recolonization 
Table 2. Ranking of the 'common' species based on mean densities $\left(\# \mathrm{~m}^{-2}\right)$ over the 2 yr study from natural substratum samples only. - Precedes each species defined in the present study as an opportunist; ${ }^{*}$ Precedes each species defined here as equilibrium type

\begin{tabular}{|c|c|c|c|c|c|}
\hline \multicolumn{3}{|c|}{ Station A, Sykes Creek } & \multicolumn{3}{|c|}{ Station B, Banana River } \\
\hline Species & $\begin{array}{c}\text { Mean } \\
\text { density }\end{array}$ & $\begin{array}{c}\text { Maximum } \\
\text { density }\end{array}$ & Species & $\begin{array}{l}\text { Mean } \\
\text { density }\end{array}$ & $\begin{array}{c}\text { Maximum } \\
\text { density }\end{array}$ \\
\hline - Corophium ellisi & 16,324 & 57,960 & •Phascolion cryptus & 454 & 1,010 \\
\hline 'Haploscoloplos foliosus & 1,841 & 5,980 & Clymenella mucosa & 369 & 1,010 \\
\hline - Capitella capitata & 1,215 & 3,850 & - Capitella capitata & 324 & 2,760 \\
\hline - Anomalocardia auberiana & 1,122 & 3,310 & - Parasterope pollex & 321 & 1,060 \\
\hline podocopan ostracod & 838 & 4,970 & diastylid cumacean & 316 & 1,610 \\
\hline Clymenella mucosa & 758 & 3,870 & $\cdots$ Ophiophragmus filograneus & 150 & 430 \\
\hline Hargeria rapax & 541 & 2,020 & $\cdots$ Tellina tampaensis & 148 & 410 \\
\hline -Tellina tampaensis & 523 & 1,010 & Melinna maculata & 143 & 290 \\
\hline - Parasterope pollex & 394 & 2,870 & Scolelepis texana & 134 & 1,290 \\
\hline Parastarte triquetra & 345 & 2,210 & Prionospio heterobranchia & 125 & 410 \\
\hline - Grandidierella bonnieroides & 298 & 1,560 & Cymodoce faxoni & 88 & 1,300 \\
\hline Gammarus mucronatus & 247 & 1,380 & - Haploscoloplos foliosus & 77 & 1,100 \\
\hline Gyptis brevipalpa & 235 & 520 & Glycinde solitaria & 63 & 200 \\
\hline Eteone heteropoda & 157 & 410 & Gyptis brevipalpa & 55 & 140 \\
\hline Polydora ligni & 124 & 1,010 & Diopatra cuprea & 55 & 160 \\
\hline Tagelus plebeius & 115 & 460 & Caecum pulchellum & 51 & 180 \\
\hline Utriculastra canaliculata & 99 & 240 & Utriculastra canaliculata & 49 & 220 \\
\hline Streblospio benedicti & 63 & 290 & Glycera americana & 33 & 120 \\
\hline Prionospio heterobranchia & 46 & 220 & Tellina versicolor & 26 & 90 \\
\hline Dorvillea rudolphi & 35 & 160 & Amygdalum papyrium & 26 & 90 \\
\hline - Ophiophragmus filograneus & 23 & 70 & & & \\
\hline Cymadusa compta & 15 & 120 & & & \\
\hline Nereis succinea & 14 & 80 & & & \\
\hline Nassarius vibex & 10 & 30 & & & \\
\hline Melinna maculata & 9 & 20 & & & \\
\hline
\end{tabular}

community (Fig. 2; Grizzle, 1981). Thus, while these 2 species were increasing their densities in some of the recolonization pans numerous other organisms were present, suggesting that competitive interactions could be important (see below). In any case, these indicator species are successful at exploiting food and space in the presence of numerous other species. At Station B the 3 equilibrium species represented $25 \%$ of the total specimens of common species collected, vs. equilibrium species representing only $2 \%$ at Station A (Table 2). These data show that the enriched conditions at Station A resulted in a shift in life history strategy of benthos toward opportunism and away from equilibrium, but also suggest that explanations other than the opportunism hypothesis are needed to explain fully the changes in community structure.

Pearson and Rosenberg (1978) and Gray (1979, 1980, 1981) discussed the opportunistic life history of several indicator species, and provided much information on the opportunism hypothesis, which appears to explain some instances of indicator dominance. However, questions remain. Thistle (1981) noted that increased food supplies may have largely affected the results of some of the recolonization studies where opportunistic species were so defined. The fact that all instances of opportunism except one in the present study were observed at the enriched Station A supports this contention. Another related aspect is competition. Gray (1981) discussed competitive interactions, but did not pose such as an explanation for indicator dominance. Capitella capitata and Streblospio benedicti, both opportunists and indicators (Pearson and Rosenberg, 1978) have been described as good competitors (Whitlatch, 1980). Santos and Simon (1980) suggested that Ampelisca abdita, a numerical dominant in their polluted study area, was a good interference competitor. They also reported that all the dominant species in the polluted area were $r$-strategists generally considered to be poor competitors (Wilson and Bossert, 1971; Pianka, 1972), yet these species rose to peak abundance over 6 to 10 mo in a community consisting of 10 to 30 species (cf. Haploscoloplos foliosus and Corophium ellisi in present study). Young and Young (1978) showed that enriching $4 \mathrm{~m}^{2}$ study areas by adding organic fertilizer resulted in significant increases in population densities of several species: $S$. benedicti, $C$. capitata, Laeoneris culveri (a density dominant in Santos and Simon's (1980) enriched study area), and Cymadusa compta. They also reported the highest densities of total macrofauna at enriched sites that were caged for predator exclusion (also see Young and Young, 1982). Perez (1976) demonstrated an immedi- 
ate and dramatic increase in densities of Polydora ligni in the benthos of an experimental microcosm after enrichment of the water column by sewage; the increase was a result of organic loading and not hypoxia because oxygen saturation was maintained at 67 to $107 \%$. Therefore, before explaining the dominance of indicator species in general and in the present study with the opportunism hypothesis, biotic interactions such as competition must be investigated.

Further implications of the above data are that 'disturbance' (meaning direct dieoff of organisms) is not required for increases to occur in the populations of some opportunists and indicators, and that benthos in these areas were food-limited. Gray (1981) noted that the role of food inputs has not been well-studied. However, the general observation of increased standing stocks of benthos in enriched areas would seem to suggest clearly food-limitation for many areas (see Objective 3 below; Young and Young, 1978; Whitlatch, 1980; Gray, 1981).

\section{Objective 3: Relate physicochemical data to macro- benthic data}

Station A macrobenthos manifested the enrichment of the water column (Table 1) by greater densities of organisms than at Station B (Fig. 3a and 4a). This enrichment effect is well-documented in many areas

Table 3. Station A, Sykes Creek, natural substratum densities taken before and after 5 Jul 1979 oxygen-temperature extreme. - Precedes each opportunist; - Precedes each equilibrium type species

\begin{tabular}{|c|c|c|}
\hline \multirow[t]{2}{*}{ Species } & \multicolumn{2}{|c|}{ \# of Organisms $\mathrm{m}^{-2}$} \\
\hline & 11 Jun & $27 \mathrm{Jul}$ \\
\hline 'Corophium ellisi & 20,240 & 10 \\
\hline 'Haploscoloplos foliosus & 5,980 & 460 \\
\hline - Capitella capitata & 2,480 & 40 \\
\hline - Anomalocardia auberiana & 640 & 60 \\
\hline podocopan ostracod & 600 & 320 \\
\hline Clymenella mucosa & 550 & 200 \\
\hline Hargeria rapax & 550 & 0 \\
\hline$\cdots$ Tellina tampaensis & 620 & 130 \\
\hline -Parasterope pollex & 50 & 0 \\
\hline Parastarte triquetra & 160 & 0 \\
\hline - Grandidierella bonnieroides & 20 & 0 \\
\hline Gyptis brevipalpa & 70 & 110 \\
\hline Eteone heteropoda & 140 & 190 \\
\hline Polydora ligni & 1,010 & 20 \\
\hline Utriculastra canaliculata & 140 & 40 \\
\hline Streblospio benedicti & 20 & 0 \\
\hline Prionospio heterobranchia & 0 & 10 \\
\hline - Ophiophragmus filograneus & 20 & 20 \\
\hline Nereis succinea & 50 & 0 \\
\hline Nassarius vibex & 0 & 20 \\
\hline Melinna maculata & 10 & 0 \\
\hline
\end{tabular}

(McNulty, 1970; Stirn, 1971; Pearson and Rosenberg, 1978; Soule et al., 1978; Reish, 1979; Dauer and Conner, 1980). Other physicochemical data and macrobenthic data revealed no correlations, with the exception of oxygen and temperature at Station A (Fig. 3). If all monthly means for oxygen and temperature are shifted forward 2 mo (e.g. correlate January oxygen and temperature with March benthic data) they show Spearman's rank correlation coefficients $\left(r_{s}\right)$ of +0.87 and -0.90 , respectively, when correlated with macrobenthic densities (Fig. 3a). These data suggest a strong relationship involving a time lag between oxygentemperature changes and macrobenthos.

Maximum temperatures in conjunction with minimum oxygen concentrations coincided (no 2 mo lag) with drastic macrobenthic density drops for three consecutive summers at Station A (Fig. 3a). If this coincidence is cause and effect, then the temperature/oxygen extremes represent a disturbance to the macrobenthos (Table 3). In summer 1978 when the pattern of oxygen/temperature extremes and macrobenthic declines was first noticed, only 2 oxygen and temperature measurements had been made in Jun and Jul 1977, and only 5 from Apr to Jul 1978. However, between 1 May and 30 Jul 1979, 27 oxygen and temperature measurements were made at Station A. This was an attempt to determine more accurately the date of occurrence of extremes of these parameters, and to relate them more precisely to macrobenthic declines. From May through Jul oxygen concentrations were consistently near or below $2.5 \mathrm{mg} \mathrm{l}^{-1}$. Maximum temperature for May was $26.5^{\circ} \mathrm{C}$; Jun had a maximum of $28.5^{\circ} \mathrm{C}$; the summer maximum of $29.5^{\circ} \mathrm{C}$ was first recorded on 5 Jul. On 11 Jun Station A macrobenthic density was 34,000 organisms $\mathrm{m}^{-2}$; on $27 \mathrm{Jul}$ it had dropped to below $2,000 \mathrm{~m}^{-2}$. Thus, for 1979 the density decrease producing minimum densities was observed just after maximum temperatures were reached in conjunction with already minimum oxygen concentrations. Large density decreases were noted for most species at Station $A$, including 3 indicator species (Table 3).

No extreme seasonal fluctuations in macrobenthos occurred at the less-polluted Station B (Fig. 4). Oxygen concentrations were significantly higher at B (Wilcoxon's signed rank test, $p<0.05$ ), presumably because of pollution effects at Station A. Temperature levels on any given date were usually within $1^{\circ} \mathrm{C}$ of Station A. Only 2 oxygen and temperature measurements were made at B during summer 1979 so adequate comparison with the 27 measurements from Station A cannot be made.

Watling (1975) reported benthic density declines similar to the present study for 3 consecutive summers associated with high water temperatures in a shallow 
Delaware estuary, but did not report oxygen data. Santos and Simon (1980) reported 3 consecutive dieoffs associated with hypoxic periods affecting all macrobenthic species present in polluted Hillsborough Bay, Florida. If the relation in Santos and Simon (1980) and my study area are based on cause and effect, then the prediction that indicators are more tolerant of hypoxia is not supported.

Oxygen/temperature limitations could explain the observed density decreases occurring coincidently with extremes of these parameters, but what of the strong correlations between temperature, oxygen, and benthic densities? Why the 2 mo lag if they are cause/ effect relations? Reish (1979) reviewed several reports showing significant impairment of reproductive abilities of 2 polychaete species at reduced oxygen concentrations. Reduced reproductive capacities could perhaps account for the lag owing to normal population control factors (e.g. predation) not being offset by possible continued recruitment. Some enriched areas with high densities of organisms may be good feeding grounds for predators (Soule et al., 1978). Virnstein (1980) reviewed several studies showing significant reductions in macrobenthic densities by predation.

\section{CONCLUSIONS}

Factors that have been shown, or are thought, to determine population sizes of macrobenthic species in coastal waters are numerous, and they can interact in complex ways (recent reviews: Boucot, 1981; Woodin, 1983). Because enrichment causes changes in populations it can be viewed as a perturbation that affects these factors. The present study has shown that population changes involving pollution indicator species in Sykes Creek can likely be explained by some combination of superior abilities related to quick invasion and exploitation of food and/or space, but a good understanding is not available. Proposed hypotheses (tolerance, opportunism, competition) should be further tested. Gray (1981) noted that few investigators have even asked (with an intent to investigate actively) why pollution indicator species are able to dominate, and he emphasized the importance of investigating this phenomenon. Because substantial changes in populations of benthic species can occur even at low levels of enrichment (Pearson and Rosenberg, 1978), and detection of the initial stages of the impacts of pollutants is of major importance, I suggest that further investigation of the proposed explanations for the dominance of indicator species in slightly-to-moderately enriched waters will provide understanding at the species level that is needed to evaluate adequately the impacts of enrichment on benthos.
Acknowledgements. Drs. Jack Stout, John Osborne, Robert Virnstein, Donald Boesch, Robert Spies, Mark Botton, and 2 anonymous reviewers provided valuable reviews of drafts of the manuscript. Drs. Virnstein and Stout gave guidance throughout the study. Mr. Kalani Cairns and Dr. Paul Mikkelsen identified voucher specimens of most species of crustaceans and molluscs. Ms. Teresa Toohey kindly provided time and talent in drawing all figures except Fig. 2. Personnel of the Brevard County Health Department lent assistance in several respects; Mr. Bill Stegner was particularly helpful during the field work. My wife, Teri, provided much needed support, especially during the latter stages of the study. The Brevard County Health Department funded the field and laboratory portions of the study.

\section{LITERATURE CITED}

Boesch, D. F., Rosenberg, R. (1981). Response to stress in marine benthic communities. In: Barrett, G. W., Rosenberg, R. (ed.) Stress effects on natural ecosystems. Wiley, New York, p. 179-200

Boucot, A. J. (1981). Principles of benthic marine paleoecology. Academic Press, New York

Cowardin, L. M., Carter, V., Golet, F. C., LaRoe, E. T. (1979). Classification of wetlands and deepwater habitats of the United States. U.S. Fish and Wildlife Service, FWS/OBS$79 / 31$

Dauer, D. M., Conner, W. G. (1980). Effects of moderate sewage input on benthic polychaete populations. Estuar. coast. mar. Sci. 10: 335-346

Filice, F. P. (1959). The effect of wastes on the distribution of bottom invertebrates in the San Francisco Bay estuary. Wasmann J. Biol. 17: 1-17

Grassle, J. F., Grassle, J. P. (1974). Opportunistic life histories and genetic systems in marine benthic polychaetes. J. mar. Res. 32: 253-284

Gray, J. S. (1979). Pollution-induced changes in populations. Phil. Trans. R. Soc. Lond. B 286: 545-561

Gray, J. S. (1980). Why do ecological monitoring? Mar. Pollut. Bull. 11: 62-65

Gray, J. S. (1981). The ecology of marine sediments. Cambridge University Press, Cambridge

Grizzle, R. E. (1979). A preliminary investigation of the effects of enrichment on the macrobenthos in an east-central Florida lagoon. Fla Scient. 42: 33-42

Grizzle, R. E. (1981). Opportunistic species of macrobenthos in a sewage-polluted lagoon, and an analysis of the indicator concept. M.S. thesis, University of Central Florida, Orlando

Hart, C. W., Fuller, S. L. H. (1979). Pollution ecology of estuarine invertebrates. Academic Press, New York

Holme, N. A., McIntyre, A. D. (1971). Methods for the study of marine benthos. IBP Handbook No. 16. Oxford and Edinburgh. Blackwell Scientific Publications

MacArthur, R. (1960). On the relative abundance of species. Am. Nat. 94: 25-36

McCall, P. L. (1977). Community patterns and adaptive strategies of the infaunal benthos of Long Island Sound. J. mar. Res. 35: 221-266

McNulty, J. K. (1970). Effects of abatement of domestic sewage pollution on the benthos, volumes of zooplankton, and the fouling organisms of Biscayne Bay, Florida. Studies in Tropical Oceanography No. 9. University of Miami Press, Coral Gables

Parry, G. D. (1981). The meanings of $r$ - and K-selection. Oecologia 48: 260-264 
Pearson, T. H. (1980). Marine pollution effects of pulp and paper industry wastes. In: Kinne, O., Bulnheim, H.-P. (ed.) Protection of life in the sea. Proceedings of the 14th European marine biology symposium. Helgoländer Meeresunters. 33: 340-365

Pearson, T. H., Rosenberg, R. (1978). Macrobenthic succession in relation to organic enrichment and pollution of the marine environment. Oceanogr. mar. Biol. A. Rev. 16: 229-311

Perez, K. T. (1976). Persistence in marine systems. In: Water quality criteria research of the USEPA, proceedings of an EPA-sponsored symposium. EPA-600/3-76-079, p. 23-30

Pianka, E. R. (1972). $\mathrm{r}$ and $\mathrm{K}$ selection or $\mathrm{b}$ and d selection? Am. Nat. 106: 581-588

Reish, D. J. (1960). The use of marine invertebrates as indicators of water quality. In: Pearson, E. A. (ed.) Proceedings of the first international conference on waste disposal in the marine environment. Pergamon Press, New York, p. 92-103

Reish, D. J. (1967). Relationship of polychaetes to varying dissolved oxygen concentrations. In: Marota, J. P., Josa, R. (ed.) Proceedings of the third international conference on water pollution research. Water Pollution Control Federation, Washington, D.C., p. 199-216

Reish, D. J. (1979). Bristle worms (Annelida: Polychaeta). In: Hart, C. W., Fuller, S. L. H. (ed.) Pollution ecology of estuarine invertebrates. Academic Press, New York, p. $77-125$

Santos, S. L., Simon, J. L. (1980). Response of soft-bottom benthos to annual catastrophic disturbance in a south Florida estuary. Mar. Ecol. Prog. Ser. 3: 347-355

Soule, D. F., Oguri, M., Soule, J. D. (1978). Urban and fishprocessing wastes in the marine environment: bioenhancement studies at Terminal Island, California. Bull. Calif. wat. poll. Cont. Ass. 15: 58-63
Stirn, J. (1971). Ecological consequences of marine pollution. Review of international oceanography of the Mediterranean, Tome XXIV, p. 13-46

Thistle, D. (1981). Natural physical disturbances and communities of marine soft bottoms. Mar. Ecol. Prog. Ser. 6: 223-228

Virnstein, R. W. (1980). Measuring effects of predation on benthic communities in soft sediments. In: Kennedy, V. S. (ed.) Estuarine perspectives. Academic Press, New York, p. 281-290

Watling, L. (1975). Analysis of structural variations in a shallow estuarine deposit-feeding community. J. exp. mar. Biol. Ecol. 19: 275-313

Whitlatch, R. B. (1980). Patterns of resource utilization and coexistence in marine intertidal deposit-feeding communities. J. mar. Res. 38: 743-765

Wilson, E. O., Bossert, W. H. (1971). A primer of population biology. Sinauer Publishers, Sunderland, Massachusetts

Woodin, S. A. (1983). Biotic interactions in recent marine sedimentary environments. In: Tevesz, M. J. S., McCall, P. L. (ed.) Biotic interactions in recent and fossil benthic communities. Topics in geobiology, Vol. 3. Plenum Press, New York, p. 3-38

Young, D. K., Young, M. W. (1978). Regulation of species densities of seagrass-associated macrobenthos: evidence from field experiments in the Indian River estuary, Florida. J. mar. Res. 36: 569-593

Young, D. K., Young, M. W. (1982). Marine macrobenthos as indicators of environmental stress. In: Mayer, G. F. (ed.) Ecological stress and the New York Bight: science and management. Estuarine Research Federation, Columbia, S.C., p. $527-539$

Zajac, R. N., Whitlatch, R. B. (1982). Responses of estuarine infauna to disturbance. I. Spatial and temporal variation of initial recolonization. Mar. Ecol. Prog. Ser. 10: 1-14

This paper was presented by Professor J. Gray; it was accepted for printing on April 19, 1984 